\title{
Keserentakan Pemilu 2024 yang Paling Ideal Berdasarkan Putusan Mahkamah Konstitusi Republik Indonesia
}

\author{
Mushaddiq Amir \\ Fakultas Hukum Universitas Indonesia \\ ${ }^{\Omega}$ Surel Koresponden: mushaddiqamir@gmail.com
}

\begin{abstract}
:
The holding of concurrent elections on April 172019 is a new history in the general election process in Indonesia. This is the implication of the Constitutional Court Decision Number 14 /PUU/2013 on the review of Law Number 42 of 2008 concerning the Election of President and Vice President. Although simultaneous elections have been considered better than previous elections, it does not mean that there are no shortcomings in the implementation. The most appalling problem is the large number of fatalities by the election organizers who are seen as the impact of the 2019 concurrent elections as well as other technical problems. Looking at various aspects raised from the 2019 elections, the Association for Elections and Democracy (Perludem) conducted a review of the material of the Law on the 1945 Constitution to the Constitutional Court as outlined in the Constitutional Court Decision Number 55/PUU-XVII/2019. In their argument, the petitioner conveys a number of things related to the analysis that has been carried out in the holding of simultaneous elections held in 2019 yesterday. In the results of the decision, the Constitutional Court rejected the petition of the petitioner in its entirety because it was considered to be groundless. However, the Constitutional Court provides choices regarding election models that can be chosen and considered constitutional based on the 1945 Constitution.
\end{abstract}

Keyword: Concurrent elections, election model, election of 2024

\begin{abstract}
Abstrak:
Terselenggaranya pemilu serentak pada tanggal 17 April 2019 merupakan sejarah baru dalam proses pemilihan umum yang ada di Indonesia. Hal ini merupakan implikasi dari Putusan Mahkamah Konstitusi Nomor 14/PUU/2013 perkara pengujian Undang-Undang Nomor 42 Tahun 2008 Tentang Pemilihan Umum Presiden dan Wakil Presiden. Meskipun pemilu serentak sudah dinilai lebih baik dari pemilu-pemilu sebelummnya bukan berarti dalam pelaksaanannya tidak memiliki kekurangan. Masalah yang paling menggemparkan adalah banyaknya korban jiwa oleh penyelenggara pemilu yang dinilai sebagai dampak pelaksanaan pemilu serentak 2019 serta masalh masalah teknis lainnya. Melihat dari berbagai sisi yang ditumbulkan dari pemilu 2019, maka Perkumpulan Untuk Pemilu dan Demokrasi (Perludem) melakukan uji materiil Undang-undang terhadap UndangUndang Dasar 1945 ke Mahkamah Konstitusi yang dituangkan kedalam Putusan Mahkamah Konstitusi Nomor 55/PUU-XVII/2019. Didalam argumentasinya, pemohon menyampaikan beberapa hal terkait dengan analisa yang telah dilakukan dalam penyelenggaraan pemilu serentak yang dilaksanakan pada tahun 2019 kemarin. Dalam hasil keputusan tersebut, Mahkamah Konstitusi
\end{abstract}


menolak permohonan pemohon untuk seluruhnya karena dianggap permohonan tersebut tidak beralasan hukum. Akan tetapi Mahkamah Konstitusi memberikan pilihan terkait model-model keserentakan pemilu yang dapat dipilih dan dinilai konstitusional berdasarkan UUD 1945.

Kata Kunci: Pemilu Serentak, Model Pemilu, Pemilu 2024

Submit : 20-09-2020 Accept : 16-10-2020

Doi: http://doi.org/10.56087/aijih.v23i2.41

\section{PENDAHULUAN}

Penyelenggaran pemilu di Indonesia seharusnya sudah dapat menetapkan sistem pemilu yang bisa diterapkan dalam waktu yang lama dengan model yang sama. Sehingga dalam setiap penyelenggaraan pemilu, tidak dibutuhkan lagi undang-undang ataupun peraturan yang baru karena sudah ada peraturan yang komprehensif dan koheren.

Pemilihan umum merupakan wujudnya nyata penerapan demokrasi di Indonesia yang memberikan peran bagi warga negara untuk dapat ikut serta secara langsung memilih pejabat publik. Hal ini membuktikan bahwa kedaulatan tetap berada ditangan rakyat. Demokrasi dan Pemilu yang demokratis merupakan "qonditio sine qua non", the one can not exist without the others. Dalam arti bahwa Pemilu dimaknai sebagai prosedur untuk mencapai demokrasi atau merupakan prosedur untuk memindahkan kedaulatan rakyat kepada kandidat tertentu untuk menduduki jabatan-jabatan politik. ${ }^{1}$ Pemilu hanyalah instrumen dan dapat dijamin berdasarkan asas konstitusi dan arah kebijakan negara yang dimaksud. Oleh karena itu, metode dapat dipertahankan atau diubah jika dipandang sebagai jalan demokrasi yang benar dalam kondisi tertentu. Penentuan suatu pilihan harus melewati banyak penelaahan pemikiran dan pengalaman untuk memastikan baik buruknya pilihan itu sendiri. ${ }^{2}$

Sistem politik di Indonesia adalah pemilihan Presiden dan Wakil Presiden secara langsung, yang merupakan wujud kedaulatan rakyat di mana rakyat dapat secara langsung menentukan siapa pemimpin pemerintahannya. ${ }^{3} \mathrm{Hal}$ ini sebenarnya bukan hal baru bagi sistem pemerintahan Indonesia, karena di setiap daerah di Indonesia yaitu di

\footnotetext{
${ }^{1}$ Junaidi, V. (2009). Menata Sistem Penegakan Hukum Pemilu Demokratis Tinjauan Kewenangan MK atas Penyelesaian Perselisihan Hasil Pemilu. Jurnal Konstitusi, 6(3), 103-143. HIm, 132

2 Ahmadi, A. (2015). Analisis Konstruksi Hukum Konstitusionalitas Pemilu Serentak Pada Tahun 2019. Al-'Adl, 8(1), 1-19, hlm 8

${ }^{3}$ Mamonto, M. A. W. W. (2019). Legal Politics of Simplifying Political Parties in Indonesia (Case Study of 2004-2014 Election). Substantive Justice International Journal of Law, 2(1), 1-20.
} 
tingkat desa masyarakat secara langsung memilih kepala kepala, melainkan baru pada tahun 2004 pemilihan kepala pemerintahan di tingkat nasional yaitu presiden dan wakil presiden yang baru. digunakan di indonesia. ${ }^{4}$ Masih banyak yang percaya bahwa pemilu ini hanya acara rutin lima tahunan yang merugikan rakyat.Hasil pemilu sendiri tidak bisa membangun masyarakat yang adil dan sejahtera atas keinginan para pendiri negara. ${ }^{5}$ Meskipun kita menyadari bahwa sebenarnya masih banyak masyarakat yang belum siap dan gagal memaknainya. Menurut Pahlevi kesiapan yang dimaksud adalah kesadaran politik yang lebih baik serta tingkat partisipasi masyarakat dalam penyelenggaraan pemilu. Jika dikatakan bahwa masyarakat sekarang sudah pintar tetapi dimaknai bahwa siapa saja yang memberikan iming-iming akan diterima tetapi ketika memilih adalah urusan pribadi, harus diubah bahwa kesadaran politik itu benar-benar dimulai sejak awal tahapan pemilihan hingga akhir pada saat memilih bahwa tidak ada istilah menolerir money politic dalam bentuk apapun. ${ }^{6}$

Dalam sejarah pelaksanaan proses pemilihan umum, pemilihan anggota legislatif dan pilpres selalu dilakukan terpisah. Hal ini membuat sebagian orang merasa bahwa pelaksanaan tersebut tidak efisien dan tidak sesuai dengan UUD 1945. Melalui permasalahan tersebut, Effendi Gazali mengajukan permohonan pengujian UndangUndang Nomor 42 Tahun 2008 tentang Pemilihan Presiden dan Wakil Presiden terhadap UUD 1945 dalam putusan MK Nomor 14/PUUXI/2013.

Terkait dengan apakah penyelenggaraan pemilu Presiden dan Wakil Presiden yang diselenggarakan setelah Pemilihan Anggota Legislatif bertentangan dengan konstitusi atau tidak, MK dalam putusannya kali ini merubah pertimbangannya. Sebelumnya dalam Putusan Nomor 51-52-59/PUU-VI/2008, bertanggal 18 Februari 2009 MK berpendapat bahwa Pasal 3 ayat (5) UU No. 42 Tahun 2008 tidak bertentangan dengan konstitusi karena hal tersebut merupakan kebiasaan, yang bisa saja memang bertentangan dengan logika hukum. Hal ini karena Presiden dan/atau Wapres dilantik oleh MPR sehingga berdasarkan logika umum, MPR harus terbentuk terlebih dahulu. Maka pemilihan DPR, DPRD, DPD lebih dulu merupakan hal yang logis. MK menyebut hal

\footnotetext{
${ }^{4}$ Azed, A. B., \& Amir, M. (2006). Pemilu dan Partai Politik Di Indonesia. Pusat Studi Hukum Tata Negara, Fakultas Hukum, Universitas Indonesia., hlm 134.

5 Triono, T. R. I. O. N. O. (2017). Menakar efektivitas Pemilu serentak 2019. Jurnal Wacana Politik, 2(2), 156-164. hlm 157

${ }^{6}$ Pahlevi, I. (2015). Pemilu serentak dalam sistem pemerintahan Indonesia. P3DI Setjen DPR RI dan Azza Grafika. hlm 30.
} 
ini sebagai desuetudo atau konvensi (kebiasaan) ketatanegaraan sehingga tidak bertentangan dengan konstitusi.

Berdasarkan putusan Nomor 14/PUU-XI/2013 ini, MK berpendapat penyelenggaraan Pilpres setelah Pemilu Anggota Lembaga Perwakilan bukan merupakan permasalahan konstitusionalitas, melainkan merupakan pilihan penafsiran konstitusional yang terkait dengan konteks pada saat putusan itu dibuat."

MK mendasarkan putusannya pada tiga hal yaitu, keterkaitan sistem pemilihan umum dengan sistem pemerintahan presidensial, dasar pemikiran dalam perumusan UUD 1945, efektivitas dan efisiensi pemilu dan hak warga negara untuk memilih dengan bijak. Dalam menganalisis poin kedua dan ketiga, secara garis besar MK sependapat dengan argumen pemohon uji materiil. ${ }^{7}$

Mengenai keterkaitan sistem pemilu dengan sistem pemerintahan presidensial, MK berpendapat bahwa dalam praktek di tahun 2004 dan 2009, sistem Pemilu menjadikan Presiden dan Wakil Presiden sangat bergantung pada dukungan DPR yang terdiri dari Partai-partai Politik agar bisa dicalonkan. Negosiasi politik juga tidak jarang terjadi untuk kepentingan taktis dan sesaat, tanpa mempertimbangkan roda pemerintahan dan manfaat jangka panjang. ${ }^{8}$ Lebih lanjut menurut MK, praktik ketatanegaraan yang berlangsung sekarang ini, dengan dilaksanakannya pemilihan presiden pasca pemilihan anggota badan perwakilan, dalam proses perkembangannya tidak dapat menjadi sarana untuk mentransformasikan sistemnya ke arah yang ideal.

Model koalisi yang dibentuk partai politik dengan calon Presiden dan Wakil Presiden justru tidak memperkuat sistem pemerintahan presidensial sebagaimana diuraikan di dalam konstitusi. Oleh karena itu, pelaksanaan pemilu presiden/wakil presiden setelah pemilu anggota legislatif tidak sesuai dengan makna pemilu sebagaimana dijelaskan dalam UUD $1945 .^{9}$

Seiring berjalannya waktu, pemilu serentak yang di selenggarakan pada tahun 2019 menyesikan berbagai macam problematika. Begitu banyak argumen yang

${ }^{7}$ Jane Aileen, Pemilu Serentak Di Tahun 2019, Kenapa Tidak Tahun Ini?, https://www.bantuanhukum.or.id/web/pemilu-serentak-di-tahun-2019-kenapa-tidak-tahun-ini/, diakses pada tanggal 18 April 2020.

8 Ibid.

${ }^{9}$ Ibid. 
mengecam penyelenggaraan pemilu serentak ini sebagai bentuk ketidaksiapan KPU sebagai penyelenggara dan faktor-faktor lainnya yang menjadikan keserentakan pemilu 5 Kotak dalam memililih Calon Presiden dan Wakil Presiden, Calon Anggota DPR, DPD, DPRD pada tingkat provinsi dan Kabupaten/Kota bukan sebagai jalan keluar. 10

Perkumpulan Untuk Pemilu dan Demokrasi (Perludem) melakukan uji materiil Undang-undang terhadap Undang-Undang Dasar 1945 ke Mahkamah Konstitusi Perludem merupakan organisasi non-pemerintahan yang bergerak dalam bidang kepemiluan yang Kegiatannya antara lain mempelajari pemilu dan demokrasi, memberikan pendidikan tentang pemilu dan demokrasi, memberikan pelatihan kepada publik tentang pemilu dan demokrasi, serta memantau jalannya pemilu dan demokrasi.Adapun putusan dalam uji materi yang di ajukan Perludem dituangkan kedalam Putusan MK Nomor 55/PUU-XVII/201911. Didalam argumentasinya, pemohon menyampaikan beberapa hal terkait dengan analisa yang telah dilakukan dalam penyelenggaraan pemilu serentak yang dilaksanakan pada tahun 2019 yang lalu.

Sebelumnya, yang menjadi pertimbangan hukum dalam Putusan Mahkamah Konstitusi Nomor 14/PUU-XI/2013 terkait penyelenggaraan pemilu serentak adalah untuk memperkuat sistem presidensil di Indonesia, menurut pemohon tidak memberikan hasil yang di inginkan. Sesungguhnya pelaksanaan pemilu serentak ini malah memperlemah posisi presiden terhadap harmonisasi pemerintahan serta agenda pembangunan, yang disebabkan tidak diserentakkannya pilkada dan pemilihan DPRD. Akibatnya, penyelenggaraan otonomi daerah yang di laksanakan oleh kepala daerah sebagai perpanjangan tangan pemerintah pusat akan menghadapui perubahan konfigurasi politik yang berfluktuasi pada saat pemilihan kepala daerah dan pemilihan anggota DPDR di tingkat provinsi dan Kabupaten / Kota sehingga akan mempengaruhi tujuan pembangunan nasional.12 Mahkamah Konstitusi melalui putusannya, yakni Putusan Nomor 14/PUUXI/2013, menegaskan bahwa ketentuan mengenai presidential threshold merupakan kebijakan hukum terbuka atau delegasi kewenangan terbuka yang

${ }^{10}$ Gai, A., \& Tokan, F. B. (2020). Analisa Dampak Penyelenggaraan Pemilu Serentak Dalam Meningkatkan Kualitas Demokrasi Di Indonesia: Studi Kasus Penyelenggraan Pemilu di Kota Kupang-Provinsi Nusa Tenggara Timur Tahun 2019. Warta Governare: Jurnal IImu Pemerintahan, 1(1), 109-128.

11 Pemohon menguji konstitusionalitas terhadap Pasal 167 ayat (3) dan Pasal 347 ayat (1) UndangUndang Nomor 7 Tahun 2017 tentang Pemilihan Umum, serta Pasal 3 ayat (1), Pasal 201 ayat(7) dan Pasal 201 ayat (2) Undang-Undang Nomor 10 Tahun 2016 tentang Pemilihan Kepala Daerah.

${ }^{12}$ Nuhrawati, A. (2018). Hukum Dan Demokrasi Jalan Menuju Kesejahteraan Rakyat. Pleno Jure, 7(2), 16-27. 
dapat ditentukan sebagai legal policy oleh pembentuk Undang-Undang. Oleh karena itu, Mahkamah Konstitusi menyerahkan persoalan presidential threshold kepada pembentuk undangundang, yakni pemerintah dan DPR. Dengan mengacu pada putusan Mahkamah Konstitusi tersebut dapat dimaknai bahwa penerapan presidential threshold dalam pemilu Presiden dan Wakil Presiden tidaklah bertentangan dengan konstitusi, demikian pula dengan penghapusan presidential threshold juga tidak bertentangan dengan konstitusi. Maka ada atau tidak adanya presidential threshold dalam pemilu Presiden dan Wakil Presiden sesungguhnya tetap konstitusional.13

Dalam penyelenggraan pemilu serentak dianggap pemohon tidak sesuai dengan asas pemilu merujuk pada kesiapan pemilu itu sendiri. Penyelenggaraan pemilu yang dinilai tidak siap tentunya bertentangan dengan tujuan pemilu yang demokratis dan konstitusional. Penting adanya sebuah kerangka hukum yang mewadahi pemenuhan prinsip kedaulatan rakyat dari segi pemilih dan aspek pemilu yang terukur dan rasional. Hal ini diharapkan dapat menciptakan pemilu yang profesional. Mampu untuk memfasilitasi hak politik setiap orang dengan adil.

Menurut pemohon, penyelenggaraan pemilu untuk memilih kepala daerah dalam hal ini pemilihan gubernur, bupati dan wakiKota apabila pelaksanaanya tidak diserentakkan dengan pemilihan anggota DPRD baik tingkat provinsi dan Kabupaten/Kota akan melemahkan pemerintahan daerah. Yang menjadi dasar akan hal ini berkaitan dengan kecenderungan akan praktik politik transaksional dan korupsi politik. Maka pemohon menginginkan agar pemilu serentak dilakukan dalam pemilihan kepala daerah dan calon anggota DPRD tingat provisinsi dan Kabupaten/Kota agar terciptanya pemilihan yang lebih demokratis.

Dalam hasil keputusan tersebut, Mahkamah Konstitusi menolak permohonan pemohon untuk seluruhnya karena dianggap permohonan tersebut tidak beralasan hukum. Akan tetapi Mahkamah Konstitusi memberikan pilihan terkait model-model keserentakan pemilu yang dapat dipilih dan dinilai konstitusional berdasarkan UUD 1945 yang diantaranya: ${ }^{14}$

13 Ansori, L. (2017). Telaah Terhadap Presidential Threshold Dalam Pemilu Serentak 2019. Jurnal Yuridis, 4(1), 15-27, hlm 20.

14 Putusan Mahkamah Konstitusi Nomor 55/PUU-XVII/2019, hlm 323-324. 
1. Pemilihan umum serentak untuk memilih anggota DPR, DPD, Presiden/Wakil Presiden, dan anggota DPRD;

2. Pemilihan umum serentak untuk memilih anggota DPR, DPD, Presiden/Wakil Presiden, Gubernur, dan Bupati/WaliKota;

3. Pemilihan umum serentak untuk memilih anggota DPR, DPD, Presiden/Wakil Presiden, anggota DPRD, Gubernur, dan Bupati/WaliKota;

4. Pemilihan umum serentak nasional untuk memilih anggota DPR, DPD, Presiden/Wakil Presiden; dan beberapa waktu setelahnya dilaksanakan Pemilihan umum serentak lokal untuk memilih anggota DPRD Provinsi, anggota DPRD Kabupaten/Kota, pemilihan Gubernur, dan Bupati/WaliKota;

5. Pemilihan umum serentak nasional untuk memilih anggota DPR, DPD, Presiden/Wakil Presiden; dan beberapa waktu setelahnya dilaksanakan Pemilihan umum serentak provinsi untuk memilih anggota DPRD Provinsi dan memilih gubernur; dan kemudian beberapa waktu setelahnya dilaksanakan pemilihan umum serentak Kabupaten/Kota untuk memilih anggota DPRD Kabupaten/Kota dan memilih Bupati dan WaliKota;

6. Pilihan-pilihan lainnya sepanjang tetap menjaga sifat keserentakan pemilihan umum untuk memilih anggota DPR, DPD, dan Presiden/Wakil Presiden;

Dengan terbitnya putusan MK diatas, menjadi menarik bagi penulis untuk membahas mengenai apa saja sebenarnya yang menjadi dampak dari pemilu serentak 2019 dari sisi partisispasi pemilih, penyelenggara pemilu dan pengaruhnya dalam sistem presidensiil di Indonesia. Kemudian menganalisa dalam mencari solusi terkait dengan model keserentakan pemilu yang ideal dilaksanakan pada tahun 2024 mendatang berdasarkan pilihan model dalam Putusan MK Nomor 55/PUU-XVII/2019.

\section{METODE}

Jenis Penelitian ini adalah yuridis normatif, yakni didefinisikan sebagai suatu prosedural penelitian ilmiah demi menemukan fakta atas logika keilmuan hukum yaitu berdasarkan norma-norma. ${ }^{15}$ Teknik pengumpulan data serta argumentasi yang dibangun dalam tulisan ini menggunakan studi kualitatif, yakni dengan mengumpulkan berbagai sumber referensi ilmiah dari sumber primer dan sumber sekunder melalui tulisan terkait seperti buku, jurnal, paper, dan berita media massa terkait dengan efektivitas penyelenggaraan pemilu serentak 2019 dan dampaknya terhadap pemilu serentak 2024.

15 Mahmud Marzuki, P. (2005). Penelitian hukum. Jakarta: Kencana Prenada Media., hlm 32. 


\section{PEMBAHASAN}

\section{Partisipasi Pemilih}

Penyelenggaraan pemilu serentak pada tahun 2019, memiliki dampak positif terhadap peningkatan partisipasi warga. Berdasarkan hasil data yang dirilis oleh Komisi Pemilihan Umum (KPU), partipasi pemilih pada pemilu serentak 2019, yakni mencapai 81,97\% pada pemilihan Presiden dan Wakil Presiden. Sementara itu, partisipasi pemilih mencapai $81,67 \%$ pada Pemilihan Legislatif. Pada pemilu-pemilu sebelumya, partisipasi pemilih dalam pemilu tahun 2014 hanya mencapai 70\% untuk Pemilihan Presiden dan 75\% dalam Pemilihan Legislatif. ${ }^{16}$ Dari data tersebut, dapat dilihat bahwasanya penyelenggaraan pemilu serentak memberikan pengaruh yang positif dalam meningkatkan partisipasi masyarakat untuk menggunakan hak pilihnya.

Melihat menigkatnya partisipasi pemilih, tidak lepas pula dari masalah yang ditumbulkannya. Menurut didik Suprianto, pemilu serentak 5 Kotak pada tahun 2019 merupakan penyelenggaraan pemilu paling rumit dan telah menciptakan beban yang berat bagi penyelenggara dan juga bagi pemilih. ${ }^{17}$ Pemilih kemudian menjadi bingung lantaran terlalu banyaknya kertas dan sosialisasi yang masih belum merata di kalangan masyarakat, sehingga terjadi perbedaan yang signifikan dalam partipasi masyarakat dalam pemilihan presiden dengan pemilihan legislatif. Menurut Pendiri Lembaga Survei Indonesi (LSI) ${ }^{18}$, dengan digabungkannya pemilu pilpres dan pileg, diskusi masyarakat terhadap pileg tidak menjadi tenggelam dan dianak tirikan karena sekitar $70 \%$ diskusi masyarakat adalah seputar pilpres dan $30 \%$ pileg.

Tingginya persentase partisipasi pemilih dalam pemilihan presiden dibandingan dengan pemilihan legislatif dikarenakan mayoritas aspek yang diliput media adalah pemilihan presiden. Sehingga informasi yang didapatkan terkait calon, visi dan misi, serta partai politik pengusung capres dan cawapres memiliki porsi yang lebih banyak dimedia dibandingkan dengan pemilihan legislatif. Sehingga banyak masyarakat asal pilih maupun

${ }^{16}$ Fitri Chusna Farisa, KPU Sebut Partisipasi Pemilih pada Pemilu 2019 Capai 81 Persen, https://nasional.kompas.com/read/2019/05/27/16415251/kpu-sebut-partisipasi-pemilih-pada-pemilu2019-capai-81-persen, diakses 12 Juli 2020.

17 Naskah dibacakan dalam Sidang Mahkamah Konstitusipada Senin 13 Januari 2019 sebagai Keterangan Ahli Pemohon Perkara 55/PUU- XVII/2019.

${ }^{18}$ Andri Saubani, Denny JA Soroti Dampak Negatif Pilpres dan Pileg Serentak, https://www.republika.co.id/berita/nasional/politik/19/04/18/pq5t85409-denny-ja-soroti-dampaknegatif-pilpres-dan-pileg-serentak, diakses pada tanggal 5 Juni 2020. 
golput dalam pemilihan legislatif. Pemilih sulit untuk memberikan rasionalitas dalam memberikan suara akibat terlalu banyaknya pilihan atau surat suara. Sehingga masuk akal jika memang seharusnya perlu dilakukan kajian ulang terkait model pemilu untuk kedepannya.

\section{Penyelenggara Pemilu}

Secara umum, ada beberapa poin yang dapat dijadikan tolak ukur dalam mengevaluasi kinerja penyelenggara pemilu. Dari aspek hukum,baik Pasal 22 E Ayat 5 UUD 1945, UU 10/2016, dan UU 7/2017 serta berbagai peraturan ataupun keputusan mengenai kepemiluan di Indonesia, penyeleggara pemilu merupakan kunci sukses tidaknya penyelenggaraan pemilu. Berkenaan dengan penyelenggaraan pemilu serentak 2019, masalah dan kendala tentu saja tidak luput dari penyelenggara pemilu. Kaitannya dalam hal ini, KPU dan Bawaslu yang merupakan penyeleggara pemilu 2019 dinilai masih belum maksimal dalam menjalankan tanggung jawabnya.

Berdasarkan hasil studi yang dilakukan oleh Indonesia Corruption Watch (ICW), Konstitusi dan Demokrasi Inisiatif (Kode Inisiatif), Perkumpulan untuk Pemilu dan Demokrasi (Perludem), dan Sindikasi Pemilu dan Demokrasi (SPD) mengkaji mengenai kinerja penyenlenggara pemilu yakni KPU dan Bawaslu. Dari sisi kemandirian KPU dan Bawaslu, ada beberapa keraguan yang menjadi pertanyaan seperti dalam pengambilan keputusan dan penyusunan peraturan terhadap verifikasi parpol sabagai peserta pemilu dimana KPU melakukan perubahan mekanisme dengan metode sampling , sedangkan yang menentuan sampel adalah parpol itu sendiri. Dari sisi profesionalisme, menurut para pakar sudah cukup baik. ${ }^{19}$ Dilihat dari kemampuan dalam membagi tugas dan peran, skala prioritas, melakukan sosiali penyelenggaraan pemilu, serta merapkan prinsip kolegial dalam mengambil keputusan.

Kontribusi dari penyelenggara pemilu lainnya seperti Polisi, Petugas KPPS, Hansip dan lain-lain juga patut di apresiasi. Khususnya peranan petugas KPPS (Kelompok Penyelenggara Pemungutan Suara). Diketahui, berdasarkan data Kementerian Kesehatan melalui dinas kesehatan tiap provinsi mencatat petugas Kelompok Penyelenggara

19 Kode Inisiatif, Evaluasi Satu Tahun Penyelenggaraan Pemilu (KPU dan BAWASLU) Periode 20172022, $\quad$ http://perludem.org/2018/05/16/hasil-evaluasi-satu-tahun-kpu-dan-bawaslu-periode-20172021/, diakses 19 September 2020. 
Pemungutan Suara ( KPPS) yang sakit sudah mencapai 11.239 orang dan korban meninggal 527 jiwa $^{20}$. Beban yang dimiliki petugas KPPS pada pemilu serentak 2019 dengan model 5 Kotak suara dianggap sangat berat. Mereka mengeluhkan tugas tersebut sangat berat karena harus dilakukan double check, sehingga bebannya pun menjadi double. Ditambah penghitungan suara harus selesai jam 10 malam dan menyiapkan formulir C1 untuk dikumpulkan esok harinya dengan personil yang hanya 7 orang saja. Melihat fenomena tersebut, tidak bisa langsung seenaknya menambahkan anggota KPPS, karena dalam PKPU Nomor 3 tahun 2019 menyatakan anggota KPPS hanya beranggotakan 7 orang saja. Langkah yang tepat untuk meminimalisir kasus seperti ini dalam keserentakan pemilu 2024 adalah dengan melakukan regulasi terhadap penambahan kuantitas personel penyelenggara sehingga ada pembagian waktu kerja dan mulai melakukan perubahan dengan memanfaatkan teknologi informasi terhadap pemungutan suara dengan metode E-Voting, penghitungan suara dengan metode $E$ Counting dan rekapitulasi suara dengan metode E-Recap.

\section{Penguatan Sistem Presidensial}

Penyelenggaraan pemilu serentak 2019 memberikan dampak yang positif terhadap penguatan sistem presidensial. Pemilu serentak menciptakan pemerintahan yang kongruen mengakibatkan partai-partai tidak punya pilihan lain, sehingga harus menggalang koalisi lebih dini sebelum pemilu mengakibatkan penyederhanakan sistem kepartaian di parlemen dimana presiden terpilih berasal dari koalisi partai yang menguasai mayoritas di parlemen. Teori terbentuknya koalisi sebelum pemilu dan coattail effect menjadi faktor penyebabnya. Stigma masyarakat yang lebih mengedapankan dan memprioritaskan pemilihan presiden, mempengaruhi keterpilihan anggota di legislatif dari partai koalisi pendukung calon presiden.Di parlemen, partai politik membawa visi dan misi partai sebagai bentuk kebijakan bagi publik dalam realisasi pemerintahan. Sehingga partai politik diparlemen tidak proporsional dalam melaksanakan tugas dan fungsinya, yaitu di dalam ke pemerintahan, baik dalam oposisi atau koalisi. ${ }^{21}$ Tujuannya adalah untuk menjaga stabilitas pemerintahan presiden terpilih

20 Sania Mashabi, Refleksi Pemilu 2019, Sebanyak 894 Petugas KPPS Meninggal Dunia, https://nasional.kompas.com/read/2020/01/22/15460191/refleksi-pemilu-2019-sebanyak-894petugas-kpps-meninggal-dunia, diakses 9 Juni 2020.

${ }^{21}$ Hayat, H. (2016). Korelasi Pemilu Serentak dengan Multi Partai Sederhana Sebagai Penguatan Sistem Presidensial. Jurnal Konstitusi, 11(3), 468-491, hlm, 484 
agara presiden mudah mendapatkan dukungan secara politik dari parlemen guna melancarkan kebijakan politik yang dibuat presiden. ${ }^{22}$

Secara konseptual, sistem presidensial adalah sistem pemerintahan yang dirancang agar jabatan-jabatan pemerintahan tidak dapat dipertanggungjawabkan kepada badan perwakilan rakyat, dengan kata lain kekuasaan eksekutif tidak berada di bawah pengawasan (langsung) parlemen. Dalam sistem ini, kedudukan eksekutif tidak tergantung pada lembaga perwakilan rakyat, adapun dasar hukum kekuasaan eksekutif dikembalikan pada pemilihan rakyat ${ }^{23}$

Menurut penelitian Scott Mainwaring, presiden jarang dipilih dari partai mayoritas. Dengan terpilihnya presiden minoritas, untuk memperoleh mayoritas di parlemen, presiden akan berusaha untuk memperkuat posisinya melalui koalisi, tetapi dalam demokrasi multi partai presidensial, jauh lebih sulit untuk membangun koalisi yang stabil. Hal ini karena aliansi tidak mengikat sehingga dalam sistem presidensial keinginan partai politik untuk membubarkan koalisi semakin kuat.24

Pengaruh berikutnya dari koalisi berbasis kesamaan ideologi ini adalah tegaknya disiplin partai politik, sehingga orientasi para politisi partai politik pun diharapkan bisa berubah dari perburuan kekuasaan menjadi perjuangan mewujudkan kebijakan. ${ }^{25}$ Apabila pilihan pemilih untuk calon anggota DPR dipengaruhi oleh pasangan calon presiden dan wakil presiden yang dipilih (coattail effect) itu benar, maka partai politik atau gabungan partai politik yang mengajukan pasangan calon presiden dan wakil presiden yang kurang baik di mata pemilih ("kurang laku dijual") cenderung akan mendapatkan suara dalam jumlah yang kecil. Apalagi melihat realitas dalam Pemilu Serentak 2019 bahwa ambang batas parlemen (parlementary threshold) mengalami kenaikan dari sebesar 3,5 persen menjadi 4 persen, maka kemungkinan besar partai atau gabungan partai politik tersebut tidak akan mampu melewati ambang batas perwakilan

22 Hanta Yuda A. R. (2010). Presidensialisme setengah hati: dari dilema ke kompromi. Gramedia Pustaka Utama, hlm 34.

${ }^{23}$ Huda, N. (2017). Penataan Demokrasi dan Pemilu di Indonesia. Kencana., hlm. 259.

24 Mainwaring, S. (1990). Presidentialism, multiparty systems, and democracy: the difficult equation (No. 144). Helen Kellogg Institute for International Studies, University of Notre Dame. hlm. 220-222, dalam https://www. researchgate.net/publication/258130109_The_Presidentialism_Multipartism_and_ Democracy The_Difficult Combination, diakses pada 7 Oktober 2020.

25 Kamil, A. B. (2017). Relevansi Pemilihan Umum Serentak Presiden Dengan Legislatif Terhadap Penguatan Sistem Presidensial di Indonesia. STAATSRECHT: Indonesian Constitutional Law Journal, 1(2). hlm 45-47. 
tersebut. Oleh karena itu, konsekuensi kedua dari penyelenggaraan Pemilu Serentak 2019 ini adalah berlangsungnya penyederhanaan jumlah partai politik secara alamiah. ${ }^{26}$ Tentu saja, kenyataan penetapan ambang batas presiden menghilangkan partisipasi partaipartai baru untuk menghindari antusiasme pencalonan presiden dan wakil presiden, serta mendukung sebagian dari pasangan calon yang resmi didaftarkan oleh KPU.

Ketentuan ambang batas presiden juga telah menyebabkan aliansi pragmatis terulang kembali, sehingga wajar jika komposisi pasangan calon pada Pilkada serentak 2019 sama dengan pada Pilpres 2014, yakni pertarungan sengit antara kubu Jokowi dan kubu Prabowo.Perubahan yang terjadi adalah hanya soal jumlah pendukung koalisi di ajang perhelatan Pemilu Serentak 2019, terlihat dengan dukungan terhadap Jokowi lebih besar daripada Prabowo. ${ }^{27}$

Dalam argumentasi pemohon yakni Perkumpulan Untuk Pemilu dan Demokrasi (Perludem) dalam Putusan MK Nomor 55/PUU-XVII/2019, menganggap model pemilu serentak lima Kotak dalam penguatan sistem presidensil tidak memberikan dampak yang signifikan. Pertimbangan hukum pada Putusan MK Nomor 14/PUU-XI-2013 terhadap hak warga negara untuk memilih secara cerdas dengan membangun peta check and balances. Pemohon merasa model pemilu serentak memang memberikan efek antara keterpilihan Presiden dan anggota DPR dari partai yang sama. Hal ini dirasa pemohon akan mengakibatkan peranan presiden dalam mengharmonisasikan agenda pemerintahan dan pembangunan, akibat, pemilihan kepala daerah dan DPRD yang tidak diserentakkan.

\section{Keserentakan Pemilu 2024 Yang Paling Ideal Berdasarkan Pilihan Model Pemilu} Serentak Berdasarkan Putusan Mahkamah Konstitusi NOMOR 55/PUU-XVII/2019

Dalam hasil Putusan MK Nomor 55/PUU-XVII/2019, Mahkamah Konstitusi menolak permohonan pemohon untuk seluruhnya karena dianggap permohonan tersebut tidak beralasan hukum. Akan tetapi Mahkamah Konstitusi memberikan pilihan terkait model-model keserentakan pemilu yang dapat dipilih dan dinilai konstitusional berdasarkan UUD 1945 yang diantaranya: ${ }^{28}$

${ }^{26}$ Haris, S. (2016). Pemilu nasional serentak 2019. Pustaka Pelajar berkerja sama dengan Electoral Research Institute (ERI), Lembaga Ilmu Pengetahuan Indonesia (LIPI)., hlm 77.

27 Efriza, E. (2019). Penguatan Sistem Presidensial Dalam Pemilu Serentak 2019. Jurnal Penelitian Politik, 16(1), 1-15., hlm 12.

28 Putusan Mahkamah Konstitusi Nomor 55/PUU-XVII/2019, hlm. 323-324. 
1. Pemilihan umum serentak untuk memilih anggota DPR, DPD, Presiden/Wakil Presiden, dan anggota DPRD;

2. Pemilihan umum serentak untuk memilih anggota DPR, DPD, Presiden/Wakil Presiden, Gubernur, dan Bupati/WaliKota;

3. Pemilihan umum serentak untuk memilih anggota DPR, DPD, Presiden/Wakil Presiden, anggota DPRD, Gubernur, dan Bupati/WaliKota;

4. Pemilihan umum serentak nasional untuk memilih anggota DPR, DPD, Presiden/Wakil Presiden; dan beberapa waktu setelahnya dilaksanakan Pemilihan umum serentak lokal untuk memilih anggota DPRD Provinsi, anggota DPRD Kabupaten/Kota, pemilihan Gubernur, dan Bupati/WaliKota;

5. Pemilihan umum serentak nasional untuk memilih anggota DPR, DPD, Presiden/Wakil Presiden; dan beberapa waktu setelahnya dilaksanakan Pemilihan umum serentak provinsi untuk memilih anggota DPRD Provinsi dan memilih gubernur; dan kemudian beberapa waktu setelahnya dilaksanakan pemilihan umum serentak Kabupaten/Kota untuk memilih anggota DPRD Kabupaten/Kota dan memilih Bupati dan WaliKota;

6. Pilihan-pilihan lainnya sepanjang tetap menjaga sifat keserentakan pemilihan umum untuk memilih anggota DPR, DPD, dan Presiden/Wakil Presiden;

Berdasarkan hasil evaluasi yang dilakukan dalam tulisan ini, model keserentakan pemilu yang paling ideal adalah Pemilihan umum serentak nasional untuk memilih anggota DPR, DPD, Presiden/Wakil Presiden; dan beberapa waktu setelahnya dilaksanakan Pemilihan umum serentak lokal untuk memilih anggota DPRD Provinsi, anggota DPRD Kabupaten/Kota, pemilihan Gubernur, dan Bupati/WaliKota. Model keserentakan pemilu tersebut dapat menjadi solusi terhadap kekurangan dan permasalahan yang dialami pada pemilu serentak tahun 2019 khususnya pada partisipasi pemilih, kinerja penyelenggara pemilu, serta penguatan sistem presidensial dan penguatan sistem pemerintahan daerah.

Dari sisi partisipasi pemilih, model diatas diharapkan mampu untuk menyeimbangakan partisipasi pemilih pada pemilihan presiden dan anggota DPR dan DPD. Dimana pada pemilu 2019 sebelumnya, meskipun persentase pemilih sudah meningkat pada pemilu-pemilu sebelumnya, akan tetapi belum dicapainya keseimbagan antara perolehan suaran dalam pemilihan presiden dan anggota legislatif. Terlalu banyaknya calon yang harus dipilih, sehingga banyak masyarakat asal pilih maupun golput dalam pemilihan legislatif. Pemilih sulit untuk memberikan rasionalitas dalam memberikan suara akibat terlalu banyaknya pilihan atau surat suara. Perhitungan suara yang tidak sah pun menungkat dari $10 \%$ pada pemilu legisltatif 2014, kemudian 
mengalami kenaikan pada pemilihan umum legislatif 2019 menjadi 11\%. Model pemilu serentak diatas, diharapkam mampu untuk mewujudkan kenyamanan pemiih dalam memberikan suara serta menjaga rasionalitas pemilih demi menghasilkan calon terpilih yang berkualitas.

Dari sisi penyelenggara pemilu, adanya jeda dan pemisahan pada pemilu nasional untuk memilih Presiden/ Wakil Presiden, dan anggota DPR dan DPRD, kemudian dilanjutakan dengan pemilihan anggota DPRD Provinsi, anggota DPRD Kabupaten/Kota, pemilihan Gubernur, dan Bupati/WaliKota. Dengan mekanisme seperti ini memberikan kesempatan untuk penyelenggara pemilu untuk bekerja dengan maksimal karena beban kerja yang tidak terlalu berat dengan tetap mengadopsi model pemilu serentak. Pertimbangan model ini dirasa mampu untuk menekan permasalahan-permasalahan yang terjadi pada pemilu serentak 2019 khususnya banyak korban jiwa oleh petugas pemilu akibat beban tugas yang terlalu berat.

Dari sisi penguatan sistem pemerintahan presidensil, model pemilu ini tetap dapat menjadi pilihan. Pemilu 2019 menunjukkan bahwa model pemilu serentak untuk memilih Presiden dan DPR terbukti menghasilkan pemerintahan yang kongruen, di mana calon presiden dan wakil presiden mendapat sebagian besar dukungan DPR dari koalisi. ${ }^{29}$ Pemerintahan yang kongruen ini yang menjadi modal utama untuk mewujudkan sistem presidensial yang efektif.

Dari sisi penguatan sistem pemerintahan daerah, berdasarkan analisa dari pemilu tahun 2019, dipisahkannya pemilihan anggota DPRD dengan pemilihan kepala daerah provinsi dan Kabupaten/Kota menjadi salah satu penyebab lemahnya pemerintahan daerah dalam memperhatikan tuntutan publik atas isu-isu daerah. Hubungan antara calon kepala daerah dengan anggota DPRD seringkali mendapati jalan buntu dalam setiap kebijakan yang diajukan oleh kepala daerah yang ditolak DPRD. Pemicunya adalah perbedaan terhadap latar politik antara kepala daerah dan DPRD. Dengan model pemilu ini, nantinya diharapkan nantinya DPRD dan kepala daerah provinsi dan Kabupaten/Kota

29 Ibid, hal, 52 dalam Didik Suprianto, Menata Ulang Jadwal Pilkada:Menuju Pemilu Nasional dan Pemilu Daerah, Penerbit Yayasan Perludem. Cetakan I, Oktober 2013, 
mampu menjalankan fungsinya di pemerintahan daerah dalam menjalankan otonomi daerah.

\section{KESIMPULAN DAN SARAN}

Dari hasil pembahasan diatas, diperlukan adanya analisa yang matang terkait dengan model pemilu serentak yang akan di adakan pada tahun 2024 mendatang. Semua aspek perlu diperhatikan mulai dari dampak bagi pemilih, dampak terhadap partai politik, dampak terhadap penyelenggara pemilu dan dampak terhadap sistem pemerintahan presidensial dan pemerintahan daerah. Dalam tulisan ini, model pemilu yang paling ideal adalah adalah Pemilihan umum serentak nasional untuk memilih anggota DPR, DPD, Presiden/Wakil Presiden; dan beberapa waktu setelahnya dilaksanakan Pemilihan umum serentak lokal untuk memilih anggota DPRD Provinsi, anggota DPRD Kabupaten/Kota, pemilihan Gubernur, dan Bupati/WaliKota. Selain itu dalam mendukung kinerja penyelenggara pemilu, pemerinah dapat melakukan terobosan dengan memanfaatkan teknologi dengan sistem e-voting dalam menunjang pelaksaan pemilu serentak 2024 mendatang. Pada masa pemilu 2024 yang akan datang, penulis berharap nantinya kekurangan dan permasalahan yang dialami pada pemilu-pemilu sebelumnya dapat dijadikan pembelajaran. Kesiapan dari segala pihak diharapkan mampu mewujudkan pemilihan umum yang demokratis. Bentuk partisipasi dari masyarakat dalam perhelatan pemilihan umum tentunya juga sangat diharapkan. Saling menghargai pilihan masingmasing tanpa harus merusak hubungan kekeluargaan.

\section{REFERENSI}

Azed, A. B., \& Amir, M. (2006). Pemilu dan partai politik di Indonesia. Pusat Studi Hukum Tata Negara, Fakultas Hukum, Universitas Indonesia.

Mahmud Marzuki, P. (2005). Penelitian hukum. Jakarta: Kencana Prenada Media.

Huda, N. (2017). Penataan Demokrasi dan Pemilu di Indonesia. Kencana.

Pahlevi, I. (2015). Pemilu serentak dalam sistem pemerintahan Indonesia. P3DI Setjen DPR RI dan Azza Grafika.

Haris, S. (2016). Pemilu nasional serentak 2019. Pustaka Pelajar berkerja sama dengan Electoral Research Institute (ERI), Lembaga Ilmu Pengetahuan Indonesia (LIPI). 
Hanta Yuda A. R. (2010). Presidensialisme setengah hati: dari dilema ke kompromi. Gramedia Pustaka Utama.

\section{Jurnal Ilmiah}

Ahmadi, A. (2015). Analisis Konstruksi Hukum Konstitusionalitas Pemilu Serentak Pada Tahun 2019. Al-'Adl, 8(1), 1-19,

Ansori, L. (2017). Telaah Terhadap Presidential Threshold Dalam Pemilu Serentak 2019. Jurnal Yuridis, 4(1), 15-27.

Efriza, E. (2019). Penguatan Sistem Presidensial Dalam Pemilu Serentak 2019. Jurnal Penelitian Politik, 16(1), 1-15.

Gai, A., \& Tokan, F. B. (2020). Analisa Dampak Penyelenggaraan Pemilu Serentak Dalam Meningkatkan Kualitas Demokrasi Di Indonesia: Studi Kasus Penyelenggraan Pemilu di Kota Kupang-Provinsi Nusa Tenggara Timur Tahun 2019. Warta Governare: Jurnal Ilmu Pemerintahan, 1(1), 109-128.

Hayat, H. (2016). Korelasi Pemilu Serentak dengan Multi Partai Sederhana Sebagai Penguatan Sistem Presidensial. Jurnal Konstitusi, 11(3), 468-491.

Junaidi, V. (2009). Menata Sistem Penegakan Hukum Pemilu Demokratis Tinjauan Kewenangan MK atas Penyelesaian Perselisihan Hasil Pemilu. Jurnal Konstitusi, 6(3), 103-143.

Kamil, A. B. (2017). Relevansi Pemilihan Umum Serentak Presiden Dengan Legislatif Terhadap Penguatan Sistem Presidensial di Indonesia. STAATSRECHT: Indonesian Constitutional Law Journal, 1(2).

Nuhrawati, A. (2018). Hukum Dan Demokrasi Jalan Menuju Kesejahteraan Rakyat. Pleno Jure, $7(2), 16-27$.

Mainwaring, S. (1990). Presidentialism, multiparty systems, and democracy: the difficult equation (No. 144). Helen Kellogg Institute for International Studies, University of Notre Dame. 
Mamonto, M. A. W. W. (2019). Legal Politics of Simplifying Political Parties in Indonesia (Case Study of 2004-2014 Election). Substantive Justice International Journal of Law, 2(1), 1-20.

Prasetyoningsih, N. (2014). Dampak Pemilihan Umum serentak bagi pembangunan demokrasi Indonesia. Media Hukum, 21(2), 23.

Stoll, H. (2015). Presidential coattails: A closer look. Party Politics, 21(3), 417-427.

Triono, T. R. I. O. N. O. (2017). Menakar efektivitas Pemilu serentak 2019. Jurnal Wacana Politik, 2(2), 156-164.

\section{Media Online}

Jane Aileen, Pemilu Serentak Di Tahun 2019, Kenapa Tidak Tahun Ini?, https://www.bantuanhukum.or.id/web/pemilu-serentak-di-tahun-2019kenapa-tidak-tahun-ini/, diakses pada tanggal 18 April 2020.

Fitri Chusna Farisa, KPU Sebut Partisipasi Pemilih pada Pemilu 2019 Capai 81 Persen, https://nasional.kompas.com/read/2019/05/27/16415251/kpu-sebutpartisipasi-pemilih-pada-pemilu-2019-capai-81-persen, diakses 12 Juli 2020.

Andri Saubani, Denny JA Soroti Dampak Negatif Pilpres dan Pileg Serentak, https://www.republika.co.id/berita/nasional/politik/19/04/18/pq5t85409denny-ja-soroti-dampak-negatif-pilpres-dan-pileg-serentak, diakses pada tanggal 5 Juni 2020.

Kode Inisiatif, Evaluasi Satu Tahun Penyelenggaraan Pemilu (KPU dan BAWASLU) Periode 2017-2022, http://perludem.org/2018/05/16/hasil-evaluasi-satu-tahun-kpudan-bawaslu-periode-2017-2021/ diakses 19 September 2020.

Sania Mashabi, Refleksi Pemilu 2019, Sebanyak 894 Petugas KPPS Meninggal Dunia, https://nasional.kompas.com/read/2020/01/22/15460191/refleksi-pemilu2019-sebanyak-894-petugas-kpps-meninggal-dunia, dikases 9 Juni 2020.

https://www. researchgate.net/publication/258130109_The_Presidentialism_ Multipartism_and__Democracy The_Difficult Combination, diakses pada 7 Oktober 2020. 